ISSN: 2302-8556

E-Jurnal Akuntansi Universitas Udayana

Vol.24.2.Agustus (2018): 1474-1502

DOI: https://doi.org/10.24843/EJA.2018.v24.i02.p24

\title{
Pengaruh Ukuran Perusahaan, Net Working Capital, Cash Flow, dan Cash Conversion Cycle pada Cash Holding
}

\author{
Cicilia Citra Liadi ${ }^{1}$ \\ I Ketut Suryanawa² \\ ${ }^{1}$ Fakultas Ekonomi dan Bisnis Universitas Udayana (Unud), Bali, Indonesia \\ email: ciciliacitraliadi14@gmail.com / Telp.089632649745 \\ ${ }^{2}$ Fakultas Ekonomi dan Bisnis Universitas Udayana (Unud), Bali, Indonesia
}

\begin{abstract}
ABSTRAK
Salah satu keputusan keuangan yang perlu dibuat oleh manajer adalah menentukan tingkat cash holding perusahaan. Menyimpan kas dengan jumlah terlalu kecil atau sebaliknya dapat memberikan pengaruh atau akibat buruk bagi perusahaan, jadi manajer perlu memperhatikan faktor-faktor yang mempengaruhi cash holding sebuah perusahaan. Tujuan penelitian adalah untuk mengetahui pengaruh ukuran perusahaan, net working capital, cash flow, dan cash conversion cycle terhadap cash holding. Penelitian ini mengambil sampel berdasarkan metode non probability sampling dengan teknik purposive sampling pada sektor industri Barang Konsumsi di BEI pada tahun 2013-2016. Jumlah sampel yang diperoleh yaitu 112 observasian. Teknik analisis yang digunakan dalam penelitian adalah analisis regresi linier berganda. Hasil yang didapatkan dari penelitian ini menunjukkan bahwa ukuran perusahaan dan cash flow berpengaruh secara signifikan terhadap cash holding, sedangkan net working capital dan cash conversion cycle tidak berpengaruh secara signifikan terhadap cash holding.
\end{abstract}

Kata Kunci: Ukuran perusahaan, net working capital, cash flow, cash conversion cycle, dan cash holding.

\begin{abstract}
One of the most important decisions made by managers is to determine the firm's cash holding rate. Saving cash in a little amount or too much money will not be good for the company, so managers need to tend the factors that affect cash holding. The purpose of this research is to know the effect of firm size, net working capital, cash flow, and cash conversion cycle to cash holding. This study took samples based on non-probability sampling method with purposive sampling technique in the Consumer Goods industry sector in BEI in 2013-2016. The number of samples obtained is 112 observations. The analysis technique used in this research is multiple linear regression analysis. The results from this research show that firm size and cash flow are significant to cash holding, while net working capital and cash conversion cycle are not significant in cash to cash holding. Keywords : Firm size, net working capital, cash flow, cash conversion cycle, and cash holding.
\end{abstract}

\section{PENDAHULUAN}

Perusahaan pada sektor industri barang konsumsi terdiri dari 5 subsektor, yaitu subsektor rokok, subsektor makanan dan minuman, subsektor peralatan rumah tangga, subsektor farmasi, serta subsektor kosmetik dan keperluan rumah tangga. 
Perusahaan pada sektor ini mempunyai perkembangan yang bagus di Indonesia, hal tersebut dapat terlihat pada berita di bawah ini. Perusahaan pada sektor ini mengalami perkembangan yang cukup pesat, sehingga membuat persaingan antar perusahaan sektor industri barang konsumsi menjadi semakin ketat. Hal tersebut menjadikan tuntutan bagi perusahaan untuk memiliki rencana dan cara yang tepat agar dapat melanjutkan usahanya.

Berita Britama pada hari Jumat, 16 September 2016 menyatakan bahwa investor asing tercatat melakukan jual bersih sebesar 140,36 miliar Rupiah pada perdagangan hari Jumat tanggal 16 September 2016. Adapun total perdagangan efek di Bursa Efek Indonesia (BEI) hari tersebut tercatat sebanyak 7,60 miliar lembar dengan nilai transaksi sebesar Rp 8,38 triliun dan indeks harga saham gabungan (IHSG) ditutup naik 1,95 poin $(+0,04 \%)$ ke level 5.267,77. Hampir separuh penggerak IHSG bergerak menguat, penguatan terbanyak terjadi pada sektor industri barang konsumsi $(+1,35 \%)$ dan pertanian $(+0,53 \%)$.

Salah satu ciri perusahaan yang baik adalah perusahaan yang memiliki likuiditas yang bagus dan membuat investor semakin menarik minatnya untuk menginvestasikan uangnya pada perusahaan. Likuiditas adalah bagaimana perusahaan mampu untuk membayar hutang jangka pendeknya. Aktiva yang paling mudah dicairkan atau mudah dipakai untuk pengeluaran adalah kas, sehingga kas dapat cepat dan mudah digunakan untuk membayar hutang jangka pendek perusahaan. Hal tersebut membuat keberadaan kas menjadi salah satu hal penting bagi perusahaan. 
Kas merupakan aset lancar yang tersedia sebagai alat transaksi atas berbagai aktifitas operasional perusahaan. Ketersediaan kas dapat membantu perusahaan dalam menunjang kelangsungan bisnis yang dijalankan perusahaan. Kemampuan perusahaan dapat dilihat dari langkah perusahaan dalam mengelola kas dengan optimal. Perusahaan harus dapat mengelola ketersedian kas dengan optimal sesuai dengan kebutuhan perusahaan karena tanpa kas yang optimal mengakibatkan perusahaan tidak dapat menjalankan aktivitas perusahaan.

Gill \& Shah (2012) mendefinisikan cash holding sebagai kas yang berada di perusahaan atau ada untuk diinvestasikan pada aset fisik serta untuk dibagikan kepada investor. Hal tersebut membuat cash holding dianggap dapat dengan mudah mengubah kas dan ekuivalen kas menjadi uang tunai. Dalam PSAK No. 2 dikatakan bahwa setara kas adalah investasi yang sifatnya sangat likuid, berjangka pendek, yang dengan cepat dapat segera dikonversikan menjadi kas dalam jumlah yang dapat ditentukan dan memiliki resiko perubahan nilai yang tidak signifikan. Salah satu keputusan keuangan penting yang dibuat oleh manajer adalah menentukan tingkat cash holding perusahaan (Ginglinger \& Saddour, 2007). Jadi, manajer harus dapat memutuskan dengan baik untuk membagikan dividen kepada para pemegang saham atau berinvestasi atau menyimpannya untuk memenuhi kebutuhan perusahaan di masa mendatang (jika terdapat aliran kas masuk).

Menyimpan kas dalam jumlah terlalu sedikit akan menyebabkan perusahaan kesulitan untuk mencukupi kebutuhan jangka pendeknya (Rahmawati, 2013). Hal tersebut dapat mengakibatkan perusahaan dianggap tidak baik dan tidak dapat menjaga dan memenuhi likuiditasnya, sehingga dapat membuat 
keraguan dan rasa ketidakmampuan dari pihak luar seperti investor dan hal tersebut dapat membuat kerugian pada perusahaan.

Menurut Keynes (1936) secara teoritis terdapat tiga motif perusahaan memiliki cash holding, yaitu: motif transaksi, motif berjaga-jaga, dan motif spekulasi. Berbeda dengan Keynes, menurut Bates et al. (2009) terdapat empat motif perusahaan memiliki cash holding, yaitu: motif transaksi, tujuan perusahaan memegang kas adalah ketika perusahaan membutuhkan kas dalam waktu terdesak perusahaan dapat mengurangi biaya likuidasi asetnya; kedua motif berjaga-jaga, tujuan perusahaan memegang kas adalah untuk mengantisipasi situasi yang tidak diprediksi dimana membutuhkan pengeluaran yang tidak terduga; ketiga motif pajak, saat dimana perusahaan memilih untuk memegang kas dan tidak membayarkannya kepada para pemegang saham karena perusahaan harus membayar pajak untuk hal tersebut; keempat motif keagenan, manajer memiliki kecenderungan memegang kas pada saat peluang investasi buruk untuk diambil bagi dirinya.

Penelitian mengenai cash holding di dunia telah banyak diteliti sebelumnya. Salah satunya diteliti oleh Sara dan Qaisar Ali yang melakukan penelitian tentang faktor yang mempengaruhi cash holding pada perusahaan nonkeuangan di Paskitan. Dalam penelitiannya menggunakan lima variabel bebas, yaitu net working capital, firm size, leverage, sales growth, dan cash conversion cycle. Hasil penelitian Sara dan Qaisar Ali menunjukkan adanya pengaruh signifikan antara variabel bebas terhadap cash holding kecuali sales growth. 
Hasil penelitian yang dilakukan oleh Senjaya \& Ketut (2015) menunjukkan investment opportunity set berpengaruh, sedangkan cash conversion cycle, dan corporate governance tidak berpengaruh. Hasil penelitian tersebut sama dengan Prasentianto (2014), yaitu cash conversion cycle tidak berpengaruh pada cash holding. Hasil penelitian yang dilakukan oleh Islam (2012) menunjukkan bahwa net working capital dan cash flow tidak berpengaruh pada cash holding.

Tujuan dari penulis melakukan penelitian ini adalah untuk mengetahui bukti empiris pengaruh net working capital, cash flow, ukuran perusahaan, dan cash conversion cycle pada cash holding. Terdapat dua manfaat dari penelitian ini, yaitu manfaat teoritis dan praktis. Manfaat teoritisnya diharapkan dapat menjadi bukti empiris serta bahan literatur bagi penelitian selanjutnya sebagai sumber referensi mengenai kebijakan cash holding yang optimal. Manfaat praktisnya diharapkan membantu perusahaan dalam mengelola cash holding guna membuat citra yang baik bagi perusahaan, keuntungan perusahaan menjadi maksimal, memperluas pangsa pasar, menghindari kegagalan perusahaan karena cash holding adalah salah satu strategi perusahaan dalam bidang keuangan.

Grand teori dalam penelitian ini adalah cash holding, balancing theory, dan pecking order theory. Menurut Gill \& Shah (2012), menjelaskan bahwa cash holding merupakan kas yang berada dan dipegang oleh perusahaan sebagai uang tunai yang mudah digunakan atau diinvestasikan pada aset lancar dan membagikannya kepada investor. Kas merupakan ukuran perusahaan dalam membayar utang tepat waktu. Cash holding penting bagi perusahaan karena 
Cicilia Citra Liadi dan I Ketut Suryanawa. Pengaruh...

memberikan kemampuan perusahaan dalam likuiditas perusahaan yaitu perusahaan mampu membayar kewajiban tepat waktu bahkan saat kondisi buruk melanda. Untuk meningkatkan penjualan dan keuntungan perusahaan harus memiliki cadangan kas sehingga akan menciptakan arus kas yang positif dan akan mempertahankan bisnis dengan hidup sejahtera.

Berdasarkan balancing theory, cash holding yang dinilai optimal adalah dengan cara membandingkan biaya yang didapat dari memegang kas tersebut dengan manfaat yang akan didapatkan perusahaan. Manfaat-manfaat yang didapatkan perusahaan dengan memiliki cash holding diantaranya adalah meminimalkan kemungkinan terjadinya financial distress, dapat membuat terpenuhinya kebijakan investasi walaupun adanya kendala pendanaan, dan meminimalkan biaya atas adanya pendanaan eksternal atau terjadinya likuidasi aset (Ferreira \& Antonio, 2004). Sementara itu, pengeluaran yang ditanggung perusahaan untuk memiliki cash holding adalah biaya yang keluar untuk modal yang dinvestasikan pada aset lancar. Menurut Opler et al. (1999) jika manajemen ingin memaksimalkan kesejahteraan para pemegang saham, maka manajer seharusnya mengatur tingkat cash holding perusahaan dengan optimal dimana biaya memegang kas dan setara kas lebih sedikit dari manfaat yang perusahaan dapatkan dari memegang kas tersebut.

Berdasarkan pecking order theory, kas dianggap mempunyai peran sebagai penopang antara laba ditahan dan kebutuhan investasi. Ketika profit yang didapat perusahaan lebih besar dari pada kebutuhan investasi, maka akan ada uang lebih dan akan menjadi kas yang tersedia di perusahaan. Myers \& Majluf (1984) 
menyatakan bahwa ketika perusahaan memiliki kas berlebih dan yakin terhadap profit yang di dapat dari investasinya, maka kelebihannya akan diberikan pada para pemegang saham dalam bentuk dividen. Menurut pecking order theory, terdapat tiga sumber asal pembiayaan perusahaan, yaitu pembiayaan internal, pembiayaan ektsernal (contoh: menerbitkan hutang), dan menerbitkan ekuitas baru.

Menurut Keynes (1936) terdapat ada tiga motif memiliki cash holding perusahaan yaitu: 1) Motif transaksi, yaitu perusahaan memegang kas untuk dipakai membayar berbagai transaksi-transaksi operasional usahanya, seperti membayar tenaga upah kerja, membayar dividen kepada para pemegang saham, dan pembelian persediaan. Salah satu tujuan perusahaan memegang kas juga adalah ketika perusahaan membutuhkan kas dalam waktu terdesak perusahaan dapat mengurangi biaya likuidasi asetnya. 2) Motif berjaga-jaga, yakni motif perusahaan untuk memegang kas atau memiliki cash holding lebih adalah untuk berjaga-jaga agar perusahaan dapat membayar pengeluaran saat menghadapi situasi yang tidak dapat diprediksi atau untuk pengeluaran biaya tidak terduga. Jika perusahaan dapat memprediksi dengan tepat dan akurat semua pengeluaran dan pemasukan kas, maka cash holding perusahaan akan lebih rendah. Selain itu, apabila perusahaan lebih mudah menggunakan sumber dana eksternal, maka cash holding perusahaan juga akan rendah. 3) Motif spekulasi, yakni salah satu tujuan perusahaan memegang kas juga adalah untuk mendapatkan keuntungan dari mempunyai atau menginvestasikan kas atau uang perusahaan dalam bentuk investasi yang bersifat sangat likuid. Jenis investasi yang biasa dipilih adalah 
sekuritas. Apabila perusahaan memperkirakan tingkat suku bunga turun, maka perusahaan akan mengubah kas miliknya menjadi saham Keynes (1936). Perusahaan berharap dengan harga saham akan naik jika semua investor mengira bahwa suku bunga akan turun.

Riyanto (2010) berpendapat bahwa net working capital adalah modal kerja bersih yang diartikan sebagai bagian dari current assets yang sungguh dapat dipakai untuk pengeluaran operasional produk perusahaan tanpa mengganggu kemampuan perusahaan untuk membayar hutang jangka pendeknya. Menurut Ferreira \& Antonio (2004) net working capital pada dasarnya dapat menjadi pengganti uang tunai atau kas. Pada saat perusahaan membutuhkan uang tunai atau pengeluaran yang tidak terduga, net working capital dapat dengan cepat dilikuidasi untuk pendanaan. Hal tersebut membuat perusahaan yang mempunyai net working capital dalam jumlah yang banyak akan lebih memilih untuk mempunyai cash holding dalam jumlah yang sedikit.

Riyanto (2010) menyatakan bahwa ukuran perusahaan dapat menjadi gambaran besar kecilnya suatu perusahaan yang dapat dilihat dari jumlah penjualan produk yang dijual perusahaan, total aktiva perusahaan, rata-rata penjualan perushaaan, dan rata-rata total aktiva yang dimiliki perusahaan. Harris \& Raviv (1990) berpendapat bahwa perusahaan besar memiliki kecenderungan untuk menginvestasikan dana yang dimilikinya pada growth opportunities yang berbeda. Hal ini bertujuan untuk melakukan usaha yang membuat keanekaragaman produk pada bagian operasional perusahaan. Dengan banyaknya diversifikasi yang dipunyai perusahaan besar dibandingkan dengan perusahaan 
kecil, hal tersebut membuat perusahaan kecil mempunyai kemungkinan besar dalam menghadapi financial distress. Perusahaan besar mempunyai jalan yang mudah ke pasar modal dengan biaya yang tidak mahal. Jika dibandingkan perusahaan kecil yang mengalami keterbatasan modal, maka perusahaan kecil lebih sulit memasuki pasar modal dengan biaya lebih murah dari perusahaan besar (Kim et al., 2011).

Cash flow adalah arus kas operasi di masa mendatang yang dipertahankan demi kelangsungan eksistensi perusahaan yang didapat dari arus kas masuk operasi dengan arus kas keluar operasi. Arus kas bersih positif terjadi jika arus kas keluar lebih sedikit daripada arus kas masuknya. Jika yang dialami sebaliknya, arus kas bersih negatif terjadi ketika arus kas keluar lebih besar dari pada arus kas masuknya. Arus kas bersih positif memberikan dampak meningkatnya jumlah saldo kas yang dipunyai oleh perusahaan. Jika terjadi sebaliknya, arus kas bersih negatif memberikan dampak menurunnya jumlah saldo kas yang dipunyai oleh perusahaan. Ogundipe et al. (2012) memperkirakan perusahaan yang memiliki tingkat cash holding yang tinggi terjadi karena perusahaan mempunyai arus kas bersih positif yang tinggi. Perusahaan akan mempunyai tingkat cash holding yang tinggi ketika mempunyai tingkat cash flow yang tinggi, hal tersebut didasari oleh pecking order theory. Hal ini terjadi karena perusahaan memiliki kecenderungan untuk memakai sumber dana internal yang dipunyainya dibandingkan sumber dana eksternal (Ozkan \& Ozkan, 2004).

Definisi cash conversion cycle menurut Syarief \& Ita (2009) merupakan ukuran perusahaan untuk mengukur berapa hari atau lamanya yang dibutuhkan 
perusahaan untuk menghasilkan kas dari hasil operasi perusahaan yang didapat dari piutang yang tertagih ditambah dengan penjualan persediaan dikurangi dengan berapa lama perusahaan membayar hutangnya. Cash conversion cycle dapat memperlihatkan berapa lama perusahaan menghasilkan produk yang dimilikinya, dari awalnya membayar biaya persediaan sampai mendapatkan kas dari penjualan produk jadi perusahaan kepada konsumen. Semakin banyaknya waktu yang dibutuhkan perusahaan untuk terjadinya siklus ini, maka semakin banyaknya perusahaan mengeluarkan uang dari dana internal yang dimiliki perusahaan untuk dapat membayar suplier (membeli bahan baku membuat produk). Semakin cepat cash conversion cycle perusahan, maka semakin cepat pula perusahaan mendapatkan kas masuk dimana kas masuk tersebut bisa dipakai sebagai investasi pada perusahaan. Seharusnya perusahaan mempunyai sekecilkecilnya jumlah persediaan yang dimilikinya (berlaku disaat perusahaan memiliki cukup produk untuk dijual ke konsumen, sehingga tidak berdampak perusahaan kehilangan penjualannya), jumlah piutang yang sekecil-kecilnya mungkin (perusahaan yang dapat mengumpulkan kas dari piutang yang tertagih dalam waktu yang cepat), serta perusahaan yang dapat menunda membayar hutang selama mungkin.

Kerangka konseptual adalah hubungan antara logika dari kajian pustaka yang telah dijelaskan dengan kajian empiris. Kerangka konseptual memperlihatkan pengaruh antara satu variabel dengan variable lainnya dalam penelitian ini. Kerangka konseptual penelitian ini dapat dilihat pada Gambar 1. di bawah ini. 


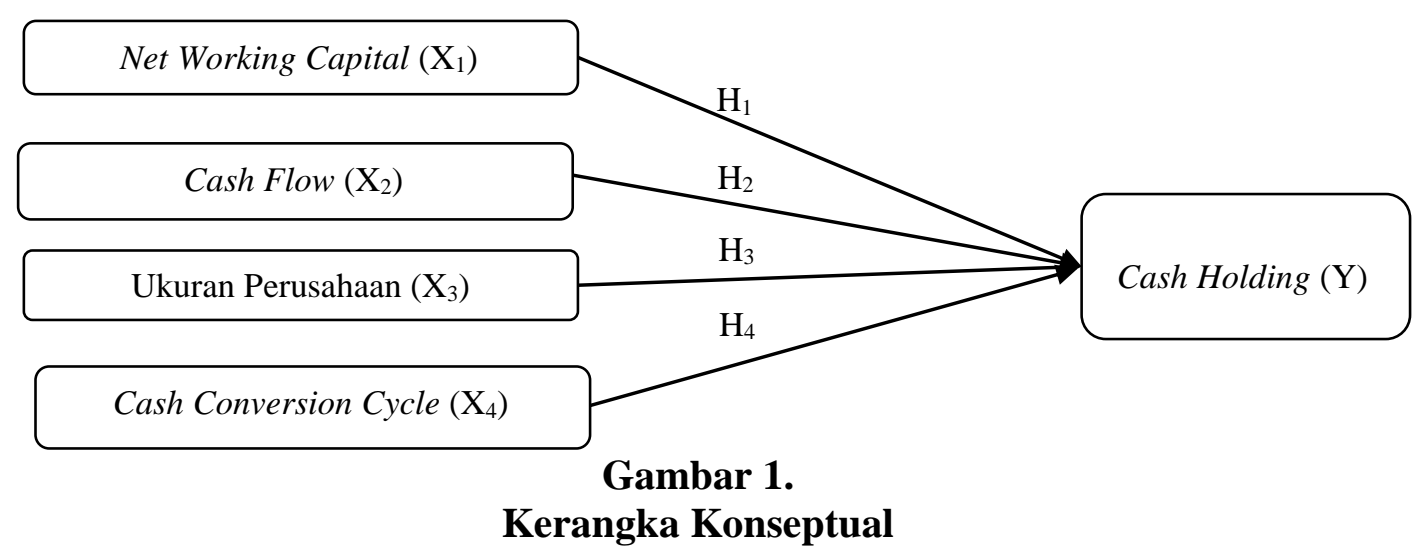

Menurut pendapat William \& Syarief (2013) net working capital memiliki kemampuan untuk bertindak sebagai substitusi terhadap cash holding perusahaan. Hal tersebut dikarenakan net working capital mudah diubah kedalam bentuk kas pada saat perusahaan membutuhkannya. Contohnya adalah piutang yang dapat mudah dilikuidasikan melewati proses sekuritisasi, selain itu perusahaan dapat dengan mudah mengubah hutang bank kedalam bentuk kas. Jika net working capital perusahaan menunjukkan negatif atau defisit, maka perusahaan dapat dikatakan sedang menjalani kesusahan pada likuiditas. Menurut Marfuah \& Ardan (2014) perusahaan akan membentuk cadangan kas jika mengalami net working capital negatif. Dalam penelitian yang diteliti Marfuah \& Ardan (2014), William \& Syarief (2013), Gill \& Shah (2012), dan Ogundipe et al. (2012), menunujukkan adanya pengaruh antara net working capital terhadap cash holding.

$\mathrm{H}_{1}$ : Net working capital berpengaruh pada cash holding perusahaan sektor industri consumer goods.

Menurut pendapat Bates et al. (2009) perusahaan akan menghasilkan memiliki tingkat jumlah kas yang tinggi apabila cash flow yang dimiliki perusahaan juga tinggi. Perusahaan mempunyai kecenderungan menahan pendapatan yang dimilikinya jika cash flow yang dimilikinya meningkat. Hal 
tersebut dilakukan agar kas yang mereka kumpulkan dapat digunakan di masa depan untuk kebutuhan investasi atau dipakai ketika terjadi financial distress (Opler et al., 1999). Ferreira \& Antonio (2004), Afza \& Adnan (2007), Bigelli \& Vidal (2009), dan Ogundipe et al. (2012) menemukan hasil terdapat pengaruh antara cash flow dengan cash holding. Berdasarkan penjelasan yang telah dibuat, maka hipotesis kedua adalah cash flow berpengaruh pada cash holding.

$\mathrm{H}_{2}$ : Cash flow berpengaruh pada cash holding perusahaan sektor industri consumer goods.

Berlandaskan pada balancing theory, ukuran perusahaan memiliki hubungan berbanding terbalik pada cash holding karena daripada menimbunnya, perusahaan besar memiliki kecenderungan untuk meginvestasikannya pada growth opportunities yang berbeda (Harris \& Raviv, 1990). Hal tersebut dikarenakan manfaat yang didapatkan lebih besar daripada biaya yang dikeluarkan oleh perusahaan besar. Perusahaan yang melakukan diversifikasi pada investasi yang dibuatnya akan mempengaruhi pada stabilnya arus kas perusahaan dan juga probabilitas yang kecil terjadinya financial distress (Titman \& Wessels, 1988). Perusahaan besar memiliki jalan atau akses yang murah dan mudah untuk mengumpulkan modal serta masuk ke pasar modal. Hasil dari penelitian yang ditulis oleh Ferreira \& Antonio (2004), Bigelli \& Vidal (2009) dan Ogundipe et al. (2012) memperlihatkan adanya pengaruh ukuran perusahaan terhadap cash holding. Berdasarkan penjelasan yang telah dibuat, maka hipotesis ketiga adalah ukuran perusahaan mempengaruhi cash holding.

$\mathrm{H}_{3}$ : Ukuran perusahaan berpengaruh pada cash holding perusahaan sektor industri consumer goods. 
Definisi cash conversion cycle menurut Syarief \& Ita (2009) merupakan ukuran perusahaan untuk mengukur berapa hari atau lamanya yang dibutuhkan perusahaan untuk menghasilkan kas dari hasil operasi perusahaan yang didapat dari piutang yang tertagih ditambah dengan penjualan persediaan dikurangi dengan berapa lama perusahaan membayar hutangnya. Cash conversion cycle dapat memperlihatkan berapa lama perusahaan menghasilkan produk yang dimilikinya, dari awalnya membayar biaya persediaan sampai mendapatkan kas dari penjualan produk jadi perusahaan kepada konsumen. Semakin cepat lama waktu cash conversion cycle, berarti bahwa perusahaan semakin cepat mendapatkan kas masuk. Setelahnya kas yang didapat tersebut dipakai kembali untuk menginvestasikannya dalam perusahaan. Hal tersebut mengakibatkan perusahaan memegang kas dalam jumlah yang tidak banyak. Berdasarkan penjelasan yang telah dibuat, maka hipotesis keempat adalah cash conversion cycle berpengaruh pada cash holding.

$\mathrm{H}_{4}$ : $\quad$ Cash conversion cycle berpengaruh pada cash holding perusahaan sektor industri consumer goods.

\section{METODE PENELITIAN}

Dalam penelitian ini mempunyai sifat asosiatif kausal merupakan penelitian yang mencari pengaruh sebab-akibat yaitu variabel bebas terhadap variabel terikatnya (Sugiyono, 2017). Penelitian ini memiliki dua variable, yaitu variable bebas dan terikat. Variabel terikatnya adalah cash holding, sedangkan variabel bebasnya adalah cash flow, net working capital, ukuran perusahaan, dan cash conversion cycle. Desain penelitiannya dapat dilihat dibawah ini pada Gambar 2. 
Pengaruh Ukuran Perusahaan, Net Working Capital, Cash Flow, dan Cash Conversion Cycle pada Cash Holding

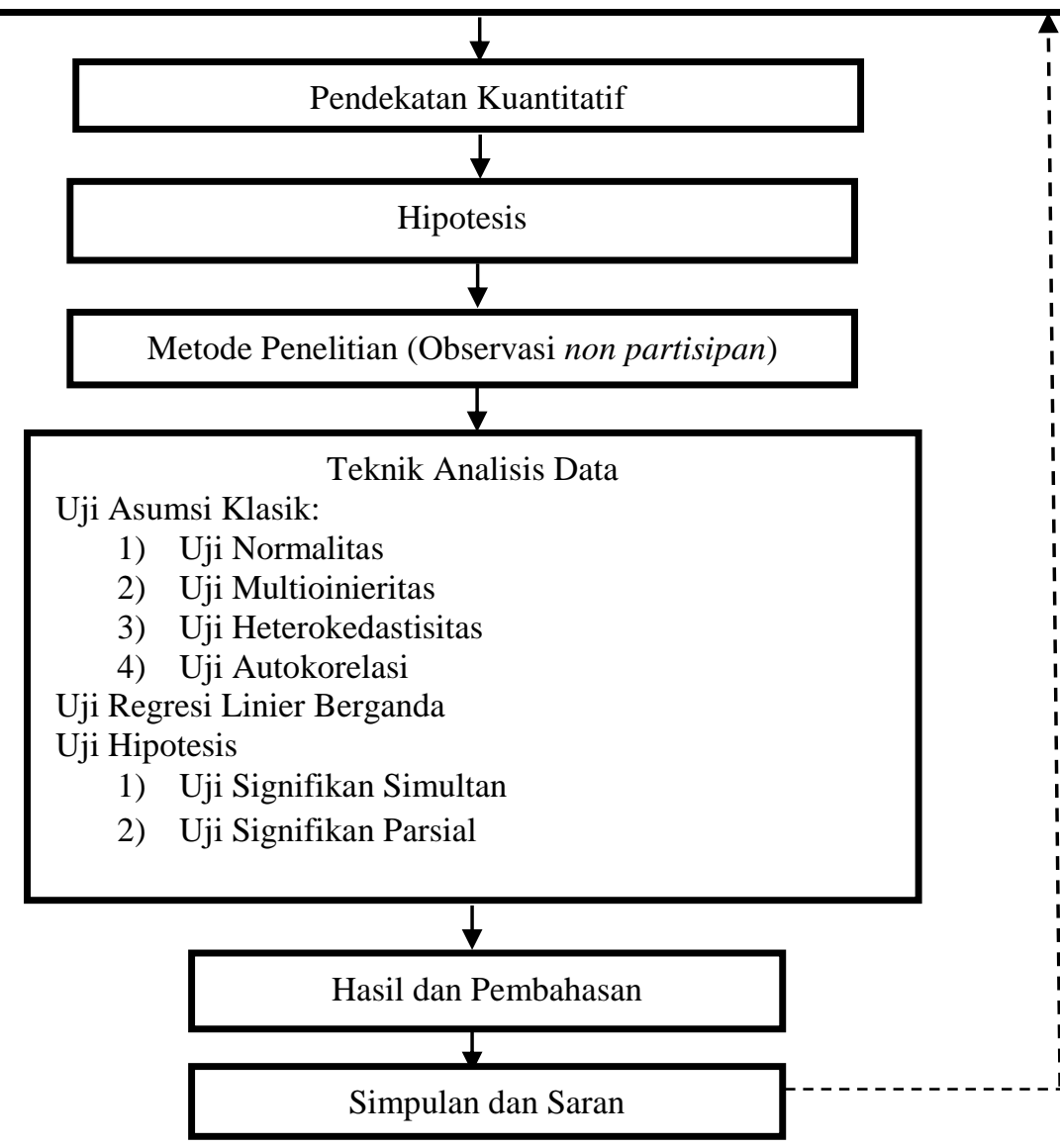

Gambar 2. Desain Penelitian

Lokasi dalam penelitian ini dilakukan pada perusahaan yang termasuk dalam sektor barang konsumsi yang terdaftar di Bursa Efek Indonesia periode tahun 2013 sampai dengan 2016 yang dapat diakses dari www.idx.co.id.

Menurut Sugiyono (2017) variabel di dalam penelitian merupakan suatu atribut dari sekelompok objek yang diteliti dan mempunyai variasi antara satu dengan yang lain dalam kelompok tersebut. Variabel terikat dilambangkan sebagai Y, adalah variabel yang dipengaruhi oleh variabel bebasnya. Variabel terikat yang dipakai dalam penelitian adalah cash holding. Cash holding adalah 
jumlah kas dan setara kas yang ada di perusahaan atau yang ditahan oleh perusahaan sebagai uang yang dipakai untuk transaksi atau dapat disalurkan melalui investasi pada aset lancar serta membagikannya kepada pemegang saham dalam bentuk dividen. Cash holding menggunakan rumus dibawah ini (Ogundipe et al., 2012).

Cash Holding $=\underline{\text { Kas dan Setara Kas }}$

Total Aset

Variabel bebas atau dilambangkan sebagai $\mathrm{X}$, yaitu variabel yang memengaruhi variabel terikat. Variabel bebas dalam penelitian ini sebagai berikut. Yang pertama adalah Net Working Capital $\left(\mathrm{X}_{1}\right)$ adalah hasil selisih atau pengurangan antara total aset lancar dengan total utang lancar (Brigham \& Houston, 2010). Berikut adalah rumus atau ukuran yang dipakai dalam penelitian ini.

Net Working Capital $=$ Aset Lancar - Utang Lancar

Yang kedua merupakan Cash Flow $\left(\mathrm{X}_{2}\right)$ adalah arus kas operasi di masa mendatang yang dipertahankan demi kelangsungan eksistensi perusahaan yang didapat dari arus kas masuk operasi dengan arus kas keluar operasi (Brigham \& Houston, 2010). Berikut adalah ukuran cash flow yang dipakai dalam penelitian ini.

$C F=$ Laba bersih + Piutang akhir - Piutang awal

Yang ketiga adalah Ukuran Perusahaan $\left(\mathrm{X}_{3}\right)$, Riyanto (2010) menyatakan bahwa ukuran perusahaan dapat menjadi gambaran besar kecilnya suatu perusahaan yang dapat dilihat dari jumlah penjualan produk yang dijual 
perusahaan, total aktiva perusahaan, rata-rata penjualan perushaaan, dan rata-rata total aktiva yang dimiliki perusahaan. Berikut adalah rumus yang dipakai dalam penelitian ini yang disesuaikan dengan Gill dan Shah (2012).

SIZ $=$ Ln Total Assets

Yang keempat adalah Cash Conversion Cycle $\left(\mathrm{X}_{4}\right)$, definisi cash conversion cycle menurut Syarief \& Ita (2009) adalah ukuran perusahaan untuk mengukur berapa hari atau lamanya yang dibutuhkan perusahaan untuk menghasilkan kas dari hasil operasi perusahaan yang didapat dari piutang yang tertagih ditambah dengan penjualan persediaan dikurangi dengan berapa lama perusahaan membayar hutangnya. Satuan waktu yang dipakai variabel cash conversion cycle merupakan hari. Berikut adalah rumus yang dipakai dalam penelitian ini yang disesuaikan dengan William \& Syarief, (2013).

$$
C C C=\text { Days Inventory }+ \text { Days Receivable }- \text { Days Payable } .
$$

Keterangan:

Days Inventory $=\frac{\text { Inventory }}{\mathrm{HPP} / 365}$

Days Receivable $=\frac{365}{\text { Account Receivable Turnover }}$

Days Payable $=\frac{365}{\text { Account Payable Turnover }}$

Account Receivable Turnover $=\frac{\text { Penjualan }}{\text { Piutang Usaha Rata-Rata }}$

Account Payable Turnover $=\frac{\text { HPP }}{\text { Utang Usaha Rata-Rata }}$

Penelitian ini menggunakan jenis data kuantiatif. Data kuantitatif dalam penelitian ini adalah laporan keuangan yang sudah di audit periode 2013 sampai dengan 2016 dan laporan tahunan yang sudah dipublikasikan oleh perusahaan periode 2013 sampai dengan 2016. Sumber data yang dipakai dalam penelitian ini merupakan data sekunder, yaitu data yang sudah ada sebelumnya. Populasi 
penelitian ini adalah perusahaan sektor industri barang konsumsi yang terdaftar di Bursa Efek Indonesia dari tahun 2013-2016. Teknik pengambilan sampel berdasarkan non-probabilitas memakai teknik purposive sampling. Purposive sampling adalah teknik penentuan sampel dengan pertimbangan tertentu (Sugiyono, 2017). Berikut adalah kriteria sampel yang dipakai dalam penelitian ini: Kriteria sampel pertama adalah perusahaan sektor industri barang konsumsi yang resmi terdaftar di Bursa Efek Indonesia periode tahun 2013 sampai dengan 2016. Kriteria sampel kedua adalah perusahaan sektor industri barang konsumsi yang mempunyai data lengkap yang dibutuhkan dalam penelitian dengan periode tahun 2013 sampai dengan 2016.

Dalam penelitian ini memakai teknik analisis regresi linear berganda, yang terdiri dari satu variabel terikat dan empat variabel bebas. Berikut adalah model persamaan regresi linier berganda penelitian.

$Y=\alpha+\beta_{1} X_{1}+\beta_{2} X_{2}+\beta_{3} X_{3}+\beta_{4} X_{4}+\varepsilon$

Keterangan:

\begin{tabular}{|c|c|}
\hline Y & $=$ Variabel Cash Holding \\
\hline$\alpha$ & $=$ Konstanta \\
\hline $\mathrm{X}_{1}$ & $=$ Variabel Net Working Capital \\
\hline $\mathrm{X}_{2}$ & $=$ Variabel Cash Flow \\
\hline $\mathrm{X}_{3}$ & $=$ Variabel Ukuran Perusahaan \\
\hline $\mathrm{X}_{4}$ & $=$ Variabel Cash Conversion Cycle \\
\hline$\beta_{1} \beta_{2} \beta_{3} \beta_{4}$ & $\begin{array}{l}=\text { Koefisien Regresi dari setiap variabel independen } \\
=\text { Kesalahan Residual (error turn) }\end{array}$ \\
\hline
\end{tabular}

Uji hipotesis yang dipakai dalam penelitian adalah uji signifikan simultan (statistik F) dan uji signifikan parsial (statistik t). Uji signifikan simultan (statistik F) dipakai untuk menguji pengaruh dari cash flow, cash conversion cycle, ukuran perusahaan, dan net working capital secara layak terhadap cash holding pada 
perusahaan sektor indutri consumer goods. Uji signifikan parsial (statistik t) menggambarkan seberapa banyak pengaruh satu variabel bebas secara parsial dalam menjelaskan variabel terikat (Ghozali, 2017). Besar signifikansi yang ditetapkan dalam penelitian adalah $0,05(\alpha=5 \%)$.

\section{HASIL DAN PEMBAHASAN}

Sampel yang dipakai dalam penelitian ini yaitu 31 perusahaan dengan total sampel sebanyak 112 data observasian. Metode pengambilan sampel yang dipakai dalam penelitian merupakan metode non-probability dengan teknik purposive sampling, yaitu teknik yang menentukan sampel yang dipilih dari populasi yang tersedia dengan menggunakan kriteria tertentu. Berikut adalah proses dan hasil dari kriteria pemilihan sampel penelitian dapat dilihat dibawah ini pada Tabel 1.

\section{Tabel 1.}

Proses dan Hasil Seleksi berdasarkan Kriteria Sampel

\begin{tabular}{|c|c|c|}
\hline No. & Keterangan & Akumulasi \\
\hline 1. & $\begin{array}{l}\text { Perusahaan yang resmi terdaftar pada sektor industri barang } \\
\text { konsumsi di BEI. }\end{array}$ & 156 \\
\hline 2. & $\begin{array}{l}\text { Perusahaan sektor industri barang konsumsi yang tidak } \\
\text { mempublikasikan laporan keuangannya selama tahun } 2013 \text { sampai } \\
\text { tahun } 2016 .\end{array}$ & $(16)$ \\
\hline 3. & Perusahaan yang sesuai kriteria & 140 \\
\hline 4. & Data outlier & $(28)$ \\
\hline \multicolumn{2}{|r|}{ Jumlah observasian yang memenuhi kriteria selama periode 2013-2016 } & 112 \\
\hline
\end{tabular}

Total populasi penelitian ini merupakan 39 perusahaan. Berdasarkan hasil proses seleksi sampel dengan purposive sampling yang ditunjukkan pada tabel 1 . diperoleh perusahaan sampel penelitian pada tahun 2013-2016 adalah sebanyak 35 perusahaan dengan sampel sebanyak 140 data observasian. Sampel berjumlah 35 perusahaan tersebut kembali di eliminasi karena 28 data mengandung outlier 
sehingga memengaruhi model yang dipergunakan. Jadi total perusahaan sampel yang dipakai dalam penelitian merupakan 31 perusahaan dengan total sampel 112 data observasian.

Uji statistik deskriptif dibawah ini berguna untuk memberitahukan info tentang karakteristik variabel dalam penelitian ini, yaitu berapa banyak jumlah sampel penelitian, berapa nilai maks dan minimumnya, seberapa besar nilai meannya, serta seberapa besar nilai standar deviasi variabel. Berikut adalah hasil statistik deskriptif dalam penelitian yang dapat dilihat di bawah ini pada Tabel 2 .

\section{Tabel 2.}

Hasil Uji Statistik Deskriptif

\begin{tabular}{lccccc}
\hline & N & Minimum & Maximum & Mean & Std. Deviation \\
\hline NWC & 112 & -4289965000000 & 27219018000000 & 2272393238714,6685 & 5355444037096,635 \\
CF & 112 & -536958000000 & 12829627250000 & 1245227979410,8662 & 2608040502510,932 \\
UP & 112 & 25,33 & 32,15 & 28,3621 & 1,62676 \\
CCC & 112 & $-181,00$ & 436,00 & 130,2589 & 86,34727 \\
CH & 112 & 0,00 & 0,26 & 0,0825 & 0,7350 \\
\hline
\end{tabular}

Sumber: Data diolah, 2018

Berdasarkan Tabel 2, dapat dijelaskan beberapa hal berikut: Penjelasan yang pertama adalah Net Working Capital mempunyai nilai mean sebesar 2272393238714,6685 dengan standar deviasi sebesar 5355444037096,635 maka dapat disimpulkan terdapat fluktuasi yang tinggi pada net working capital di perusahaan yang menjadi sampel. Nilai minimum sebesar -4289965000000 dimiliki oleh perusahaan UNVR dan nilai maksimum sebesar 27219018000000 dimiliki perusahaan HMSP.

Penjelasan yang kedua adalah Cash Flow mempunyai nilai mean sebesar 1245227979410,8662 dan standar deviasinya 2608040502510,932 maka dapat disimpulkan terdapat fluktuasi yang tinggi pada cash flow di perusahaan yang 
menjadi sampel. Nilai minimumnya -536958000000 oleh perusahaan BUDI dan nilai maksimumnya 12829627250000 oleh perusahaan HMSP.

Penjelasan yang ketiga adalah Ukuran Perusahaan mempunyai nilai mean sebesar 28,3621 dan standar deviasinya 1,62676 maka dapat disimpulkan terdapat fluktuasi yang rendah pada ukuran perusahaan pada perusahaan yang menjadi sampel penelitian. Nilai minimumnya 25,33 dipunyai oleh perusahaan KICI dan nilai maksimumnya 32,15 dipunyai oleh perusahaan INDF.

Penjelasan yang keempat adalah Cash Conversion Cycle mempunyai nilai mean sebesar 130,2589 dan standar deviasi sebesar 86,34727 maka dapat disimpulkan terdapat fluktuasi yang rendah pada cash conversion cycle di perusahaan yang menjadi sampel. Nilai minimumnya $-181,00$ dipunyai oleh perusahaan BTEK dan nilai maksimumnya 436,00 dpunyai oleh perusahaan MRAT.

Penjelasan yang kelima adalah Cash Holding mempunyai nilai mean sebesar 0,0825 dan standar deviasinya 0,7350 maka dapat disimpulkan terdapat fluktuasi yang tinggi pada cash holding di perusahaan yang menjadi sampel. Nilai minimumnya 0,00 dipunyai oleh perusahaan HMSP dan nilai maksimumnya 0,26 dipunyai oleh perusahaan TSPC.

Ghozali (2017) menyatakan bahwa uji normalitas mempunyai tujuan untuk menguji apakah dalam model regresi, variabel penggunaan atau residual memiliki distribusi normal atau tidak. Diketahui bahwa uji signifikan simultan (statistik F) dan uji signifikan parsial (statistik t) diasumsikan bahwa nilai residual mengikuti 
distribusi normal. Dalam penelitian ini, pengujian untuk uji normalitas yang dipakai adalah uji statistik Kolmogrov-Smirnov Test.

Berikut adalah dasar uji statistik Kolmogrov-Smirnov Test: Yang pertama adalah apabila angka sig. lebih besar daripada 0,05, maka dapat dikatakan bahwa data berdistribusi normal. Yang kedua adalah apabila angka sig. lebih kecil daripada 0,05, maka dapat dikatakan bahwa data tidak berdistribusi normal. Berikut adalah hasil uji statistik Kolmogrov-Smirnov Test yang dapat dilihat dibawah ini pada tabel 3 .

Tabel 3.

Hasil Uji Normalitas

\begin{tabular}{ccc}
\hline $\mathbf{N}$ & $\mathbf{Z}$ & Asymp. Sig \\
112 & 0,076 & 0,127 \\
\cline { 2 - 3 } Data diolah, 20188 &
\end{tabular}

Berdasarkan Tabel 3, hasil uji statistik Kolmogorov-Smirnov memperlihatkan bahwa nilai asymp. signifikansinya sebesar 0,127. Dapat terlihat bahwa nilai asymp. signifikansinya lebih besar daripada 0,05, jadi dapat disimpulkan bahwa data terdistribusi normal.

Menurut pendapat Ghozali (2017) uji multikolinearitas mempunyai tujuan untuk mencari tahu atau menemukan adanya korelasi antara satu variabel bebas dengan lainnya. Apabila model regresi terbebas dari multikolinieritas atau tidak terjadi multikoliniearitas, maka model regresi tersebut sudah dapat dikatakan baik. Multikolinearitas ditunjukkan melalui nilai tolerance dan Variance Inflation Factor (VIF). Apabila nilai tolerancenya lebih besar daripada 0,01 atau nilai Variance Inflation Factor lebih kecil daripada 10, maka dapat dikatakan tidak 
terjadi multikolinearitas. Berikut adalah hasil uji multikolinieritas yang dapat dilihat dibawah ini pada tabel 4.

Tabel 4.

Hasil Uji Multikolinearitas

\begin{tabular}{ccc}
\hline Variabel & \multicolumn{2}{c}{ Colliniearity Statistic } \\
& Tolerance & VIF \\
\hline Net Working Capital & 0,383 & 2,612 \\
Cash Flow & 0,356 & 2,806 \\
Ukuran Perusahaan & 0,362 & 2,764 \\
Cash Conversion Cycle & 0,855 & 1,170 \\
\hline Sumber: Data diolah, 2018 & &
\end{tabular}

Tabel 4 menunjukkan bahwa untuk semua variabel independen cash flow, net working capital, ukuran perusahaan dan cash conversion cycle mempunyai nilai VIF yang lebih kecil daripada 10 serta nilai tolerance yang lebih besar dari 0,01. Jadi, dari hasil uji tersebut dapat disimpulkan bahwa tidak terjadi multikolinieritas antara satu variabel independen dengan variable independen lainnya.

Menurut pendapat Ghozali (2017) uji heteroskedastisitas mempunyai tujuan untuk mencari tahu model regresi yang diteliti mengalami ketidaksamaan varian antar residual pengamatannya. Uji heteroskedastisitas dalam penelitian ini memakai grafik plot antara nilai prediksi variabel dependen yaitu ZPRED dengan residualnya SRESID. Berikut adalah hasil uji heteroskedastisitas yang dapat dilihat dibawah ini pada Gambar 3 . 


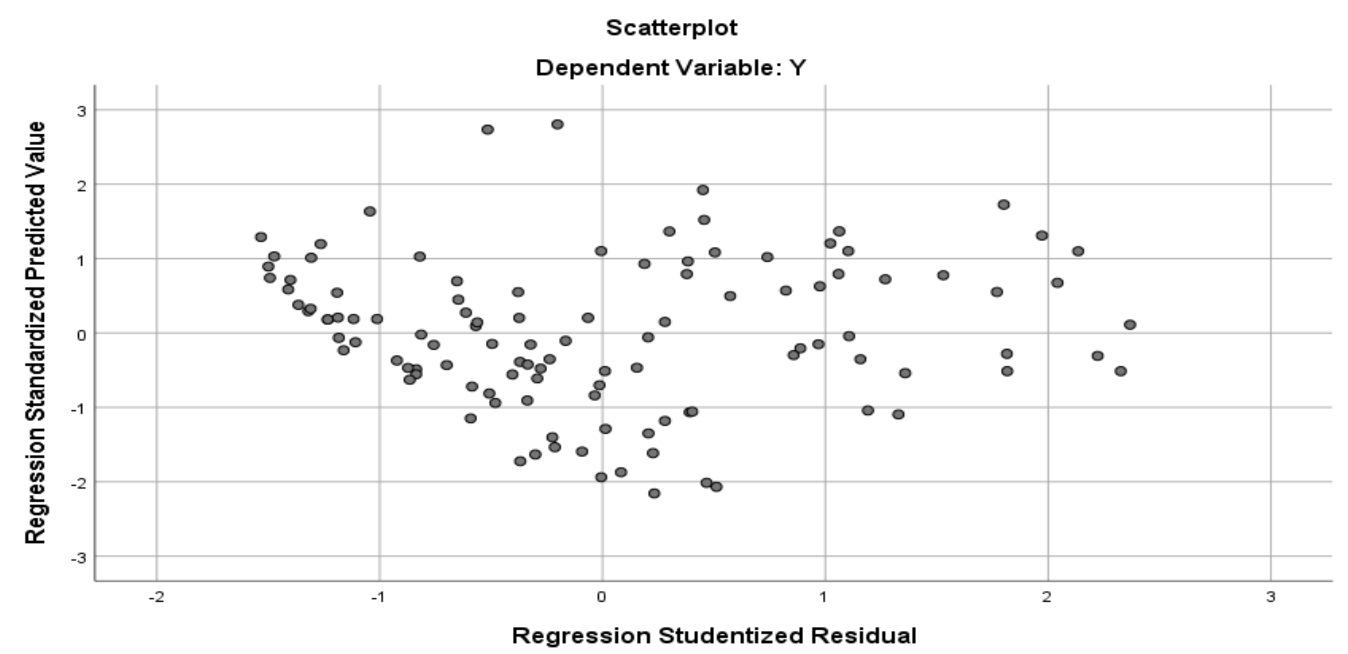

Gambar 3.

Hasil Uji Heteroskedastisitas

Gambar 3. menunjukkan bahwa tidak terdapat pola yang jelas dan juga menyebarnya titik-titik secara merata pada atas dan bawah angka 0 pada sumbu Y. Dari penjelasan di atas dapat dikatakan bahwa pada model regresi tidak terjadi heteroskedastisitas.

Uji autokorelasi bertujuan untuk menguji apakah didalam suatu model regresi linier terdapat korelasi antara kesalahan pengganggu pada periode $t$ dengan kesalahan pengganggu pada periode t-1 (Ghozali, 2017). Dalam penelitian ini memakai uji Durbin Watson (DW) untuk menguji autokorelasi model regresinya dengan persyaratan apabila du lebih kecil daripada dw lebih kecil daripada (4 du) maka dapat dikatakan bahwa model regresi tidak terjadi autokorelasi. Berikut adalah hasil uji autokorelasi yang dapat dilihat dibawah ini pada Tabel 5.

Tabel 5.

Hasil Uji Autokorelasi

\begin{tabular}{cc}
\hline DW (Durbin Watson) & Keterangan \\
\hline 1,977 & $\mathrm{du}<\mathrm{dw}<(4-\mathrm{du})$ \\
\hline Sumber: Data diolah, 2018 &
\end{tabular}


Cicilia Citra Liadi dan I Ketut Suryanawa. Pengaruh...

Tabel 5. menunjukan nilai Durbin Watson (DW) sebesar 1,977. Berdasarkan tabel DW dengan jumlah sampel sebanyak 112 serta jumlah variabel bebas empat diperoleh nilai upper boung (du) sebesar 1,7664 serta 4 - du sebesar 2,2336. Dapat dilihat nilai DW sebesar 1,977 berada diantara nilai du 1,7664 dan empat dikurangi nilai du sebesar 2,2336, dengan demikian maka $\mathrm{H}_{\mathrm{o}}$ diterima atau tidak terjadi autokorelasi.

Analisis regresi liniear berganda dipakai untuk mengetahui apakah suatu variabel bebas mempunyai pengaruh terhadap variabel terikatnya atau tidak. Berikut adalah hasil dari uji regresi linier berganda yang dapat dilihat dibawah ini dalam Tabel 6.

Tabel 6.

Hasil Uji Regresi Linier Berganda

\begin{tabular}{lccccc}
\hline \multicolumn{1}{c}{ Model } & \multicolumn{2}{c}{ Unstandardized Coefficients } & $\begin{array}{c}\text { Standardized } \\
\text { Coefficients }\end{array}$ & t & Sig. \\
\cline { 2 - 4 } & $\mathbf{B}$ & Std. Error & Beta & & \\
\hline (Constant) & $-0,592$ & 0,183 & & $-3,231$ & 0,002 \\
X1 & $2,911 \mathrm{E}-15$ & 0,000 & 0,212 & 1,526 & 0,130 \\
X2 & $-1,602 \mathrm{E}-14$ & 0,000 & $-0,596$ & $-3,946$ & 0,000 \\
X3 & 0,025 & 0,006 & 0,544 & 3,804 & 0,000 \\
X4 & $-7,012 \mathrm{E}-5$ & 0,000 & 0,082 & $-0,886$ & 0,378 \\
Adjusted R & 0,179 & & & \\
F hitung & 7,046 & & & & \\
Sig. F & 0,000 & & & &
\end{tabular}

Berdasarkan tabel 6. model regresi yang terbentuk dalam penelitian ini dapat dilihat dibawah ini.

$\mathrm{Y}=-0,592+2,911 \mathrm{E}-15 \mathrm{X} 1+-1,602 \mathrm{E}-14 \mathrm{X} 2+0,025 \mathrm{X} 3+-7,012 \mathrm{E}-5 \mathrm{X} 4$

Variabel net working capital mempunyai nilai sig. sebesar 0,130 yang memiliki arti bahwa nilai sig. lebih besar dari signifikansi $\alpha$ yaitu 0,05 . Hal tersebut berarti bahwa net working capital tidak berpengaruh signifikan pada cash holding. Variabel cash flow mempunyai nilai sig. sebesar 0,000 yang memiliki arti 
bahwa nilai sig. lebih kecil dari signifikansi $\alpha$ yaitu 0,05 . Hal tersebut berarti bahwa cash flow berpengaruh signifikan pada cash holding. Variabel ukuran perusahaan mempunyai nilai sig. sebesar 0,000 yang memiliki arti bahwa nilai sig. lebih kecil dari signifikansi $\alpha$ yaitu 0,05 . Hal tersebut berarti bahwa ukuran perusahaan berpengaruh signifikan pada cash holding. Variabel cash conversion cycle mempunyai nilai sig. sebesar 0,376 yang memiliki arti bahwa nilai sig. lebih besar dari signifikansi $\alpha$ yaitu 0,05 . Hal tersebut berarti bahwa cash conversion cycle tidak berpengaruh signifikan pada cash holding.

\section{SIMPULAN}

Penelitian ini mempunyai tujuan untuk mengetahui pengaruh dari net working capital, cash flow, ukuran perusahaan, dan cash conversion cycle pada cash holding perusahaan sektor industri barang konsumsi yang terdaftar di Bursa Efek Indonesia periode 2013-2016. Berdasarkan dari hasil analisa dan pembahasan yang dibuat maka terdapat beberapa kesimpulan sebagai berikut:

Kesimpulan yang pertama adalah variabel net working capital tidak berpengaruh signifikan pada cash holding perusahaan sektor industri barang konsumsi yang terdaftar di Bursa Efek Indonesia periode 2013-2016. Kesimpulan yang kedua adalah variabel cash flow berpengaruh signifikan pada cash holding perusahaan sektor industri barang konsumsi yang terdaftar di Bursa Efek Indonesia periode 2013-2016.

Kesimpulan yang ketiga adalah variabel ukuran perusahaan berpengaruh signifikan pada cash holding perusahaan sektor industri barang konsumsi yang terdaftar di Bursa Efek Indonesia periode 2013-2016. Kesimpulan yang keempat 
adalah variabel cash conversion cycle tidak berpengaruh signifikan pada cash holding perusahaan sektor industri barang konsumsi yang terdaftar di Bursa Efek Indonesia periode 2013-2016.

Berikut adalah saran-saran yang dapat disampaikan berlandaskan analisa dan kesimpulan yang telah dibuat dalam penelitian: Saran peneliti yang pertama adalah perusahaan yang terdaftar dalam sektor industri barang konsumsi di Bursa Efek Indonesia diharapkan dapat lebih memperhatikan cash flow dan mengembangkan kinerja perusahaan menjadi lebih baik lagi, sehingga perusahaan menjadi lebih besar dan mudah memasuki pasar. Hal tersebut membuat pendanaan menjadi lebih sedikit dibandingkan perusahaan kecil. Perusahaan juga sebaiknya dapat mengelola net working capital, cash flow, ukuran perusahaan, dan cash conversion cycle sehingga dapat menentukan tingkat cash holding perusahaan dengan tepat.

Saran peneliti yang kedua adalah para investor dan calon investor diharapkan mampu memperhatikan nilai cash conversion cycle, cash flow, net working capital, dan ukuran perusahaan sebagai bahan pertimbangan dalam berinvestasi. Saran peneliti yang terakhir adalah diharapkan penelitian selanjutnya dapat memakai variabel lain yang mungkin dapat dijadikan variabel independen seperti variabel bank debt. Selain itu, harapan bagi penelitian selanjutnya dapat dilakukan pada sektor lain, seperti sektor perbankan.

\section{REFERENSI}

Afza, T., dan Adnan, S. M. 2007. Determinants of Corporate Cash holdings: A Case Study of Pakistan. Proceedings of Singapore Economic Review Conference (SERC) 2007, August 01-04, Organized by Singapore 
Economics Review and the University of Manchester (Brooks World Poverty Institute).

Anjum, Sara dan Qaisar Ali Malik. 2013. Determinants of Corporate Liquidity An Analysis of Cash Holdings. IOSR Journal of Business and Management. ISSN: 2278-487X, Vol. 7, Issue 2.

Anonim. 2016. IHSG Tutup Stagnan, Sektor Industri Barang Konsumsi Melonjak 1,35\%.https://britama.com/index.php/2016/09/ihsg-tutup-stagnan-sektorindustri-barang-konsumsi-melonjak-135/. Diakses 8 Agustus 2017.

Bates, Thomas W. et al. 2009. Why Do U.S. Firms Hold So Much More Cash Than They Used To?. The Journal Of Finance, Vol. LXIV, No. 5.

Bigelli, M., dan Vidal, J.S. 2012. Cash Holding in Private Firms. Journal of Banking and Finance, Vol. 36, pp. $26-35$.

Brigham dan Houston. 2010. Dasar-Dasar Manajemen Keuangan, Buku 1 Edisi 11. Jakarta: Salemba Empat

Ferreira, Miguel A, dan Antonio S. Vilela. 2004. Why Do Frims Hold Cash? Evidence from EMU Countries. European Financial Management, Vol. 10, No. 2

Ghozali, Imam. 2017. Aplikasi Analisis Multivariate dengan Program IBM SPSS 23. Semarang: Badan Penerbit Universitas Diponegoro

Gill, Amajit, dan Shah Charul. 2012. Determinant of Coorporate Cash Holdings : Evidence from Canada. International Journal of Economics and Finance, Vol. 4 (1), January 2012. College of Business Administration, Trident University Internasional.

Ginglinger, E., \& Saddour, K. 2007. Cash Holdings, Corporate Governance and Financial Constraints.https://hal.archives-ouvertes.fr/halshs00162404/document. Diakses 20 Juni 2017.

Harris, M. dan Raviv, A. 1990. Capital Structure and the Informational Role of Debt. Journal of Finance, Vol. 45, pp. 321-49.

http://www.idx.co.id

Ikatan Akuntan Indonesia (IAI). 2017. Laporan Arus Kas. Pernyataan Standar Auntansi Keuangan No. 2 (Revisi 2017). Jakarta: DSAK-IAI

Islam, Sohani, 2012. Manufacturing Firm Cash Holdings Determinants: Evidence from Bangladesh. Journal International of Business and Management. Vol. 7 (6).

Keynes, John M. (1936). The General Theory of Employment. Interest and Money. London: Macmillan. 
Kim, J.Y, Kim, H.J., dan Woods, D. 2011. "Determinants of Corporate CashHolding Levels: An Empirical Examination of The Restaurant Industry." International Journal of Hospitality Managemet, Vol. 30, pp. 568-574.

Marfuah, dan Ardan Zulhilmi. 2014. Pengaruh Growth Opportunity, Net Working Capital, Cash Conversion Cyrcle, dan Leverage Terhadap Cash Holding Perusahaan. Jurnal Universitas Islam Indonesia.

Myers, S. C., dan Majluf, N. 1984. Corporate Financing Decisions When Firms Have Information that Investors Do Not Have. Journal of Financial Economics 13, pp. 187-221.

Ogundipe, Lawrencia Olatunde, Ogundipe, Sunday Emmanuel dan Ajao, Samuel Kahinde, 2012. Cash Holdings and Firm Characteristics: Evidence from Nigerian Emerging Market. Journal of Business, Economics \& Finance, vol.1 Issue. 2

Opler, T., L. Pinkowitz, R. Stulz, dan R. Williamson. 1999. The Determinants and Implications of Corporate Cash Holding. Journal of Financial Economics, 52 (1), 3-46

Ozkan, Aydin, dan Ozkan, N,. 2004. "Corporate Cash Holdings: An Empirical Investigation of UK Companies". Journal of Banking and Finance, Vol. 28 (9), 2103-2134.

Prasentianto, Hanafi. 2014. Analisis Faktor-Faktor yang Mempengaruhi Tingkat Cash Holding (Studi Empiris pada Perusahaan Property dan Real Estate yang Terdaftar di Bursa Efek Indonesia Tahun 2009-2013). Skripsi Sarjana Jurusan Manajemen pada Fakultas Ekonomika dan Bisnis Universitas Diponegoro, Semarang

Rahmawati, Zahrotul Auliya. 2013. Faktor-Faktor yang Mempengaruhi Keputusan Cash Holding pada Perusahaan Food and Beverages yang Terdaftar di Bursa Efek Indonesia. Jurnal Manajemen Fakultas Ekonomi dan Bisnis. Universitas Brawijaya.

Riyanto, Bambang. 2010. Dasar-Dasar Pembelanjaan Perusahaan, ed. 4. Yogyakarta: BPFE

Saddour, Khaoula. 2006. The Determinants and the Value of Cash Holdings: Evidence from French firms. Centre de Recherchess sur la Gestion. Universite Paris Dauphine.

Senjaya, Sheryl Yuliana dan I Ketut Yadnyana. 2015. Analisis Pengaruh Investment Opportunity Set, Cash Conversion Cycle, dan Corporate Governance Terhadap Cash Holding. Tesis. Universitas Udayana.

Sugiyono. 2017. Statistika Untuk Penelitian. Bandung: Alfa Beta. 
Syarief, Moch. Ednan, dan Ita Prihatining Wilujeng. 2009. Cash Conversion Cycle dan Hubungannya dengan Ukuran Perusahaan, Profitabilitas, dan Manajemen Modal Kerja. Jurnal Ekonomi dan Bisnis, Vol. 14, No. 1.

Titman, S. and R. Wessels 1988. The Determinants of Capital Structure Choice. The Journal of Finance, Vol. 43, No. 1. Mar, pp. 1-19.

William, dan Syarief Fauzi. 2013. Analisis Pengaruh Growth Opportunity, Net Working Capital, dan Cash Conversion Cycle terhadap Cash Holdings Perusahaan Sektor Pertambangan. Jurnal Ekonomi dan Keuangan, Vol 1, No. 2. 